American Journal of Applied Sciences 6 (3): 445-448, 2009

ISSN 1546-9239

(C) 2009 Science Publications

\title{
HER2 Protein Overexpression in Infiltrating Ductal Carcinoma of the Breast Associated with Lymph Node Involvement
}

\author{
Adrienne Pratti Lucarelli, Maria Marta Martins, Vilmar Marques Oliveira, \\ Maria Antonieta Longo Galvão, João Marcelo Guedes, José Francisco Rinaldi, Tsutomo Aoki and \\ Sebastião Piato \\ Department of the Gynecology and Obstetrics, Department of the Santa Casa de São Paulom, \\ Faculty of Medical Sciences, Sóror Angélica street, 705 11-A CEP 02452-060 São Paulo, SP, Brazil
}

\begin{abstract}
The current study compares the rates of overexpression of the HER2 protein in stage II ductal carcinoma of breast in patients with lymph-node involvement. The research material was tissue sections obtained from the primary tumor of 28 patients with lymph-node involvement. The technique used to detect the protein was immunohistochemistry. The overexpression of HER2 protein occurred in $33.3 \%$ of lymph node-positive patients. Subsequently, the lymph-node metastases population was divided into two subgroups: one subgroup having involvement of up to three lymph nodes and the second subgroup with the involvement of four or more lymph-nodes. In the first group the level of HER 2 overexpression was $7.7 \%$ and in the second subgroup the HER2 overexpression was $63.6 \%$. The difference was statistically significant.
\end{abstract}

Key words: Breast cancer, immunohistochemistry, HER-2, lymph-node metastasis

\section{INTRODUCTION}

The HER2 protein is one of the four proteins of the HER family which has as its homologue the EGFR, also known as HER-1 ${ }^{[1-3]}$. This protein presents a stimulating response upon the cell when it binds to specific activators that circulate in the extracellular space and are denominated as ligands ${ }^{[4]}$.

Initially, the molecules of the HER2 proteins are monomeric (n) and extracellular. They become dimeric (2n) at moment when recruitment of the other molecule of the protein occurs. Binding the ligand to the extracellular domain, dimerizartion occurs in the cell membrane and, in the cytoplasm of the tumor cell, a three-dimensional alteration of the receptor dimer occurs. This alteration stimulates the tyrosine kinase activity which controls a series of nuclear transcription factors ${ }^{[3,5,6]}$.

The overexpression of the HER2 protein usually results from the increase of its coding by the c-erb-b2 gene; therefore, it is commonly found to be associated to the amplification of this proto-oncogene $e^{[7-10]}$.

The increase of HER2 expression becomes even more important when this protein participates in the formation of heterodimers. When the latter is bound to the HER3 receptor, hyperactivity of cell signaling pathway occurs, leading to high levels of cell cycle regulation, with the emergence of a situation of uncontrolled growth and cell proliferation, with consequent tumorigenesis ${ }^{[11]}$.

Concerning the role of the HER2 protein in the dissemination of breast cancer, it is considered that the fundamental event consists in the association of this protein to the heregulin ligand ${ }^{[12]}$.

The overexpression of this protein in breast cancer has been associated to disease aggressiveness, a more reserved prognosis, absence of estrogen and progesterone receptors, as well as resistance to hormonal and chemotherapy using cyclophosphamide, methotrexate and fluracil ${ }^{[13]}$. On the other hand, the protein has been a valuable object of study for specific anticancer therapy with humanized murine monoclonal antibody, known as trastuzumab ${ }^{[14]}$.

\section{MATERIALS AND METHODS}

For this study, tissue fragments of the primary tumors were used from 28 women with infiltrating ductal carcinoma of the breast, having clinical staging of II. The patients were assisted in the Central Hospital of the Irmandade da Santa Casa de Misericórdia de São Paulo and in Saint Isabel's Hospital, in the period between November, 1999 and 2004.

Corresponding Author: Adrienne Pratti Lucarelli, Department of the Gynecology and Obstetrics, Department of the Santa Casa de São Paulom, Faculty of Medical Sciences, Sóror Angélica street, 705 11-A CEP 02452-060 São Paulo, SP, Brazil Tel: (55+11)22364827 Fax: (55+11)22585090 
Am. J. Applied Sci., 6 (3): 445-448, 2009

In 10 patients, removal of the primary lesion was done by mastectomy, in 18 patients by quadrantectomy, with ipsilateral complete axillary lymphadenectomy. The surgical specimens were fixed in formaldehyde at $10 \%$ and conserved in paraffin blocks.

The patients were divided into two groups according to the state of the axillary lymph nodes: Group 1, composed of 15 patients with up to three affected lymph nodes and Group 2, composed of 13 patients with four or more metastatic axillary lymph nodes.

The exclusion criteria for this study included chemotherapy or neoadjuvant radiotherapy and the association of breast cancer to pregnancy.

The immunohistochemical technique was used for slide preparation and for the semiquantatative evaluation of the HER2 protein expression in the cytoplasmic membrane of the neoplastic cells, the compound prepared by the DAKO Corporation was used, which has been approved for use by the Food and Drug Administration (FDA) of the USA.

The semiquantatative evaluation of the HER2 expression was done subjectively using the following interpretation criteria: negative/absent (0), when the brown-sepia color was not observed in the cell membrane, low $(+)$, when the color was weak and partially delimitated the cells, moderate $(++)$, when the color was weak, but complete in the cell contour and high $(+++)$, when the color was strong and encircled the entire cytoplasmic membrane.

Overexpression regarding HER2 was only considered in the tumors with +3 expression. For the pathologists, the interpretation of the immunohistochemical method is relatively simple in cases in which the HER2 was non-detectable (0) or has low expression $(+1)$, as well as for those that presented a strong positive expression $(+3)$. As to the moderate expression $(+2)$, it was verified that its concordance with gene amplification, established by the FISH method, did not exceed $25 \%{ }^{[15]}$.

In order establish a comparison between the groups for the qualitative variables, the chi-squared test was used. The existence of a statistically significant association was considered when the descriptive level (p-value) found was lower than 0.05 .

\section{RESULTS AND DISCUSSION}

In Table 1 the results are presented concerning the association of the HER2 protein expression with the number of affected axillary lymph nodes in the 28 patients of the two groups. Recoding of the protein expression is presented in Table 2.
Table 1: HER2 expression in the primary tumors of the 28 patients with affected axillary lymph nodes

\begin{tabular}{llllr}
\hline \multicolumn{5}{c}{ Affected lymph nodes } \\
& \multicolumn{5}{c}{ Up to 3 } & More than 3 \\
& \multicolumn{5}{c}{ lymph nodes } & lymph nodes & Total \\
\hline HER2 & $\mathrm{N}$ & 6.0 & 2.0 & 8.0 \\
Absent & N & 40.0 & 15.4 & 28.6 \\
& $(\%)$ & 6.0 & 2.0 & 8.0 \\
+1 & $\mathrm{~N}$ & 40.0 & 15.4 & 28.6 \\
& $(\%)$ & 2.0 & 2.0 & 4.0 \\
+2 & $\mathrm{~N}$ & 13.3 & 15.4 & 14.3 \\
& $(\%)$ & 1.0 & 7.0 & 8.0 \\
+3 & $\mathrm{~N}$ & 6.7 & 53.8 & 28.6 \\
& $(\%)$ & 15.0 & 13.0 & 28.0 \\
Total & $\mathrm{N}$ & 100.0 & 100.0 & 100.0 \\
& $(\%)$ & &
\end{tabular}

Table 2: HER2 expression in the primary tumors of the 28 patients with affected lymph nodes (excluding patients with +2 classification)

\begin{tabular}{llllr}
\hline & & Linfonodos comprometidos & \\
& & Up to & More than & \\
& & 3 lymph nodes & 3 lymph nodes & Total \\
\hline HER2 & & & & \\
$0 \mathrm{e}+1$ & $\mathrm{~N}$ & 12.0 & 4.0 & 16.0 \\
& $(\%)$ & 92.3 & 36.4 & 66.7 \\
+3 & $\mathrm{~N}$ & 1.0 & 7.0 & 8.0 \\
& $(\%)$ & 7.7 & 63.6 & 33.3 \\
Total & $\mathrm{N}$ & 13.0 & 11.0 & 24.0 \\
& $(\%)$ & 100.0 & 100.0 & 100.0 \\
\hline
\end{tabular}

$\mathrm{p}=0.004$

Based on the statistical analysis, we can affirm that there was an association between the variables, indicating that there is a greater percentage of strong expression among the patients with more than three involved lymph nodes.

With the goal of improving the prognosis of women affected by breast cancer, several researchers have aimed to develop new therapeutic strategies, especially those that are based on the overexpression of the HER2 protein on the primary tumor cells ${ }^{[16-18]}$. In 1998, trastuzumab was approved by the Food and Drug administration of the USA for the treatment of breast cancer metastasis in patients with HER2 overexpression. Several clinical trials have evidenced that patients affected by breast cancer, in which the neoplastic cells of the primary tumor present high immunoexpression (+3), benefit from the adjuvant treatment using this medication ${ }^{[17,19]}$.

In associating the number of lymph nodes in the 24 women with affected axillae (4 patients were excluded having a +2 expression), it was verified that the rate of overexpression $(+3)$ was of $7.7 \%$ in the subgroup with up to three affected lymph nodes by metastasis and of $63.6 \%$ in those with more than three lymph nodes. 
Concerning the first subgroup, our results are in accordance with those obtained by Tandon et al.$^{[10]}$, yet our rate was considerably more elevated in relation to the second.

As demonstrated, other authors also obtained rates of overexpression of HER2 in the primary tumor of women affected by breast cancer proportional to the affected axillary lymph nodes ${ }^{[7,9,20]}$. The existence of the association between HER2 overexpression with the number of involved axillary lymph nodes observed by several authors and by our research team in the present study seems to indicate that this protein plays a relevant role in breast cancer dissemination.

The results obtained in this study, in addition to those observed by other authors that performed similar investigations evidenced the advantage of researching the presence of HER2 protein overexpression in neoplastic cells of the primary breast cancer lesions, regardless of the axillary lymph node state. Once this information becomes available, the doctor will be able to indicate with greater precision the use of more intensive adjuvant therapy, aiming to achieve better survival rates in women affected by breast cancer.

\section{CONCLUSION}

In comparing the group of patients with axillary metastasis, it was verified that the HER2 overexpression was significantly greater in subgroup with four or more affected lymph nodes in comparison to those with only three affected lymph nodes.

\section{REFERENCES}

1. Borg A, Baldetorp B, Ferno M, Killander D, Olsson H, Sigurdsson H, 1991, ERBB2 amplification in breast cancer with a high rate of proliferation, Oncogene 6(1):137-43.[PubMed]

2. Berns EM, Klijn JG, van Staveren IL, Portengen H, Noordegraaf E, Foekens JA, 1992, Prevalence of amplification of the oncogenes c-myc, HER2/neu, and int -2 in one thousand human breast tumours: correlation with steroid receptors, Eur J Cancer, 28(2-3):697-700.doi:101016/S0959-8049 80129-7.

3. Bertucci F, Borie N, Ginestier C, Groulet A, CharafeJauffret E, Adelaide J, Geneix J, Bachelart L, Finetti P, Koki A, Hermitte F, Hassoun J, Debono S, Viens P, Fert V, Jacquemier J, Birnbaum D, 2004, Identification and validation of an ERBB2 gene expression signature in breast cancers, Oncogene, 23(14):2564-75. doi:10.1038/sj.onc.1207361
4. Dickson RB, Lippman ME. Oncogenes and suppressor genes. In: Harris J., Lippman ME, Morrow M.; Hellman S. Diseases of the Breast, Philadelphia: Lippincott 2000 2nd edition:281-302.

5. Hynes NE, Stern DF,1994, The biology of erbB$2 /$ neu/HER-2 and its role in cancer. Biochim. Biophys. Acta, 1198(2-3):165-84.[PubMed]

6. Seidman AD, Berry $\mathrm{D}$, Cirrincione C, Harris L, Muss H, Marcom PK, Gipson G, Burstein H, Lake D, Shapiro CL, Ungaro P, Norton L, Winer E, Hudis J,2008, Randomized phase III trial of weekly compared with every-3-weeks paclitaxel for metastatic breast cancer, with trastuzumab for all HER-2 overexpressors and random assignment to trastuzumab or not in HER-2 nonoverexpressors: final results of Cancer and Leukemia Group B protocol 9840.J Clin Oncol, 26(10):16429.doi:10.1200/JCO.2007.11.6699.

7. Pinkas-Kramarski R, Shelly M, Guarino BC, Wang LM, Lyass L, Alroy I, Alimandi M, Kuo A, Moyer JD, Lavi S, Eisenstein M, Ratzkin BJ, Seger R, Bacus SS, Pierce JH, Andrews GC, Yarden Y, 1998, ErbB tyrosine kinases and the two neuregulin families constitute a ligand-receptor network. Mol Cell Biol, 18(10):6090-101.doi:02707306/98/\$04.00+0

8. van de Vijver MJ, Peterse JL, Mooi WJ, Wisman P, Lomans J, Dalesio O, Nusse R, 1998, Neu-protein overexpression in breast cancer. Association with comedo-type ductal carcinoma in situ and limited prognostic value in stage II breast cancer, $\mathrm{N}$ Engl J Med., 319(19):1239-45. [PubMed]

9. Berger MS, Locher GW, Saurer S, Gullick WJ, Waterfield MD, Groner B, Hynes NE,1998, Correlation of c-erbB-2 gene amplification and protein expression in human breast carcinoma with nodal status and nuclear grading, Cancer Res,48(5):123843.http//cancerres.aacrjournals.org/cgi/reprint/48/5/1238.

10. Borg A, Tandon AK, Sigurdsson H, Clark GM, Ferno M, Fuqua SA, Killander D, McGuire WL, 1990, HER-2/neu amplification predicts poor survival in node-positive breast cancer, Cancer Res, 50(14):4332-37 http//cancerres.aacrjournals.org/cgi/reprint/50/14/4332.

11. Tandon AK., Clark GM, Chamness GC, Ullrich A and McGuire WL, 1989. HER-2/neu oncogene protein and prognosis in breast cancer. J Clin. Oncol., 7: 1120-1128. [Pubmed]

12. Neve RM, Lane HA, Hynes NE, 2001, The role of overexpressed HER2 in transformation, Ann Oncol, 12(suppl 1):S9-13.[PubMed]

13. Adam L, Vadlamudi R, Kondapaka SB, Chernoff J, Mendelsohn J, Kumar R,1998, Heregulin regulates cytoskeletal reorganization and cell migration through the p21-activated kinase-1 via phosphatidylinositol-3 kinase, J Biol Chem, 273(43):2823846.http//www.jbc.org/cgi/content/full/273/43/28238 
14 Mueller-Holzner E, Fink V, Frede T, Marth C, 2001, Immunohistochemical determination of HER2 expression in breast cancer from core biopsy specimens: a reliable predictor of HER2 status of the whole tumor, Breast Cancer Res Treat, 69(1):139.doi:10.1023/A:1012281221647.

15. Beatty BG, Bryant R, Wang W, Ashikaga T, Gibson PC, Leiman G, Weaver DL, 2004, HER-2/neu detection in fine-needle aspirates of breast cancer: fluorescence in situ hybridization and immunocytochemical analysis, Am J Clin Pathol, 122(2):246-255. doi:10.1309/X8UP920UF4XM1C5C

16.Rubin I, Yarden Y, 2001, The basic biology of HER2, Ann Oncol 12 Suppl.1:S3-8. http//gateway1.ovid.com/ovidweb.cgi

17. Thor A, 2001, HER2- a discussion of testing approaches in the USA, Ann Oncol,12 Suppl 1:S101-7.[PubMed]
18. Eppenberger-Castori S, Kueng W, Benz C, Caduff R, Varga Z, Bannwart F, Fink D, Dieterich H, Hohl M, Muller H, Paris K, Schoumacher F, Eppenberger U,2001, Prognostic and predictive significance of ErbB-2 breast tumor levels measured by enzyme immunoassay, J Clin Oncol, 19(3):645-56.

http//jco.ascopubs.org/cgi/content/full/19/3/645.

19. Kaptain S, Tan LK, Chen B, 2001. Her-2/ neu and breast cancer, Diagn. Mol. Pathol, 10(3): 139-52. http//gateway2.ovid.com/ovidweb.cgi

20. Slamon DJ, Clark,G.M, Wong, SG, Levin,WJ, Ullrich A, McGuire WL. 1987, Human breast cancer: correlation of relapse and survival with amplification of the HER-2/neu oncogene. Science, 235(4785):177-82,1987. doi:10.1126/science.3798106. 